\title{
EHMTI-0061. Do the interictal microembolic signals have a role in higher cortical dysfunctions during migraine aura?
}

\author{
A Podgorac $^{1 *}$, I Petrusic ${ }^{1}$, J Zidverc-Trajkovic ${ }^{2}$, A Radojicic ${ }^{2}$, Z Jovanovic ${ }^{3}$, N Covickovic-Sternic ${ }^{3}$ \\ From 4th European Headache and Migraine Trust International Congress: EHMTIC 2014 \\ Copenhagen, Denmark. 18-21 September 2014
}

\section{Introduction}

Higher cortical functions (HCF) impairment during aura in migraine patients is more frequent than previously thought.

The aim of this study was to evaluate prevalence and clinical impact of interictal microembolic signals (MES) in migraine patients with HCF disturbances during aura.

\section{Method}

This study was carried out on 68 patients (34 migraineurs with higher cortical functions (HCF) disturbances during the aura (HCD group) and 34 migraineurs with only visual or visual and sensory symptoms (Control group I) and 31 healthy controls (Control group II). Demographic data, disease features and detected MES between these groups were analyzed. Furthermore, patients with HCF disturbances were analyzed according to presence of MES.

\section{Results}

There was no statistically significant difference in terms of gender, age at the time of examination and age at the time of the onset of disease between three groups. Aura was longer $(34.71 \pm 18.05$ vs. $23.87 \pm 13.64, \mathrm{p}=0.002)$ and frequency of aura per year was higher $(16.29 \pm 14.21$ vs. $10.10 \pm 11.00, \mathrm{p}=0.029)$ in the HCD group as compared to the Control group I. Also, sensory aura was significantly more present in HCD group ( $\mathrm{p}<0.001)$. MES were detected in 10 (29.4\%) patients from HCD group, which was significantly higher compared to $1(3.2 \%)$ in Control group I and $2(5.9 \%)$ in Control group II $(\chi 2=$ $7,909, \mathrm{p}=0.005 ; \chi^{2}=6,476, \mathrm{p}=0.011$ ).

${ }^{1}$ School of Medicine, University of Belgrade, Belgrade, Serbia

Full list of author information is available at the end of the article

\section{Conclusion}

High prevalence and frequency is detected in migraine patients with HCF disturbances during aura. The exact pathophysiological mechanism of this finding is not clear and requires additional investigations.

No conflict of interest.

\section{Authors' details}

${ }^{1}$ School of Medicine, University of Belgrade, Belgrade, Serbia. ${ }^{2}$ Headache Center, Neurology Clinic CCS, Belgrade, Serbia. ${ }^{3}$ Department for Cerebrovascular disorders and Headaches, Neurology Clinic CCS, Belgrade, Serbia.

Published: 18 September 2014

doi:10.1186/1129-2377-15-S1-E27

Cite this article as: Podgorac et al:: EHMTI-0061. Do the interictal microembolic signals have a role in higher cortical dysfunctions during migraine aura? The Journal of Headache and Pain 2014 15(Suppl 1):E27.

Submit your manuscript to a SpringerOpen ${ }^{\circ}$ journal and benefit from:

- Convenient online submission

- Rigorous peer review

- Immediate publication on acceptance

- Open access: articles freely available online

- High visibility within the field

- Retaining the copyright to your article

Submit your next manuscript at $>$ springeropen.com 